\title{
The Mediating Effect of Attitude on Customers' Behavioural Intention to Participate in Islamic Banking: Empirical Evidence
}

\author{
Ibrahim Abiodun Oladapo ${ }^{1}$, Normah $\mathrm{Omar}^{2}$, Ruhaini Muda ${ }^{2} \&$ Abdulazeez Adewuyi Abdurraheem ${ }^{3}$ \\ ${ }^{1}$ Department of Economics, College of Business Administration, Imam Abdulrahman Bin Faisal University, Dammam, \\ Kingdom of Saudi Arabia \\ ${ }^{2}$ Accounting Research Institute, Universiti Teknologi MARA, Malaysia \\ ${ }^{3}$ Islamic Business School, College of Business, Universiti Utara, Malaysia \\ Correspondence: Ibrahim Abiodun Oladapo, Department of Economics, College of Business Administration, Imam \\ Abdulrahman Bin Faisal University, Dammam, Kingdom of Saudi Arabia.
}

Received: April 30, 2019

doi:10.5430/ijfr.v10n5p167
Accepted: May 30, 2019

Online Published: June 10, 2019

URL: https://doi.org/10.5430/ijfr.v10n5p167

\begin{abstract}
Purpose - This paper examines the mediating effect of positive attitude (ATT) and subjective norm (SJN) on customers' behavioral intention to participate in Islamic banking in Nigeria using the Theory of Reasoned Action (TRA) as a basis.

Design/methodology/approach - Data were collected using a self-administered questionnaire with 274 samples. This study used the convenience sampling technique.

Findings - The authors found a positive and significant relationship between the factors in the model. The findings highlight the relevance of attitude in the structural model. The findings further show that attitude has a positive effect in mediating the relationship between awareness, knowledge, religion and the behavioural intention of customers.

Originality/value - This paper highlights the need for policymakers, regulators and Islamic banking operators to create proper awareness through effective communication with customers on the benefits of Islamic banking and the provision of a platform for knowledge enhancement to promote a positive attitude among the different segments of society and which in turn can influence their intention to participate in Islamic banking.
\end{abstract}

Keywords: Islamic banking, theory of reasoned action, mediation, policymakers, Nigeria

\section{Introduction}

The Islamic finance industry has continued to record an impressive growth since it came into existence in the last few decades (Global Islamic Finance Forum, 2014). The total assets of the Islamic finance industry was valued at \$1.67trillion in 2013 (Ernst \& Young, 2013) and over \$2 trillion in 2014 growing at an annual rate of 17\% (IFSB, 2014). This has placed the Islamic finance sector at a higher position within the global Islamic economy, hence, according it recognition both at the domestic and the international fronts. Given the large Muslim population of about 1.7 billion of the global population controlling about $\$ 6.7$ trillion of the world's gross domestic product (GDP), and the growing desire for Shari'ah-compliant financial activities which prohibits unlawful financial transactions such as charging interest, Islamic finance remains the most exciting and vibrant financial and economic phenomenon (Hasan; 2005; Tag el-Din, 2005; Dar, 2012; Gyebi, Owusu \& Etroo 2013). Many countries both Muslim and non-Muslim, have established Islamic banks to cater for the needs of the people. Pakistan, Iran and Sudan for instance, were among the first to adopt a single banking system that sought to fully implement Shari'ah principles and make Islamic financial system as mainstream for their banking and economic activities. Similarly, Malaysia, United Arab Emirates, Kuwait, Bahrain, Saudi Arabia, Nigeria, and most recently Morocco, among others, operate a dual banking system whereby conventional and Islamic banks are allowed to co-exist within a national market. However, in spite of the efforts, many still cannot access funds. The threat is even more severe for Sub-Saharan Africa countries like Nigeria.

In the context of Nigeria, the banking system has always been dominated by conventional banks until 2012 when the central bank of Nigeria (CBN) approved the first and the only full-fledged Islamic bank. The central bank came up with a framework for the regulation and supervision of non-interest financial institutions. This initiative, if well 
implemented, will put the Islamic banking sector in the country at a better position and also contribute to its growth and development. The likely challenges that could impede the success of this industry would include customers' perceptions particularly on the operations of the bank, its compliance with Shari'ah, available qualified manpower and its outreach amongst others. However, there is no empirical research so far in this direction to guide the bank in its decisions and policies. Hence, the need for an empirical investigation to help better understand the specific situations with regard to customers' needs and expectations of Islamic banking in Nigeria.

This study constitutes part of the effort directed at generating empirical work on Islamic banking. We applied the theory of reasoned action (TRA) to investigate Nigerian customers' attitude towards Islamic banking as well as their intention for patronage (Jermsittiparsert, 2016). This study is necessary because the behavioural intentions of Nigerian customers will indicate to the government whether the establishment of Islamic banking constitutes a worthy task. Against this backdrop, this study sought to empirically examine the intention of Nigerians to patronize Islamic banks. This is in view of their level of education, exposure and religious commitment, which are necessary factors in shaping the intention of this category of people.

\section{Literature Review}

\subsection{The Profile of Nigeria}

Nigeria is situated in the West African region. It is ranked the seventh most populous country in the World and the most populous country in the African continent with an estimated population of over 182 million people (World Bank, 2016). There are currently 36 states in the country including the capital city which are divided into 6 geo-political zones namely: North-West, North-East, North-Central, South-West, South-East and South-South. Historically, the population of Nigeria comprised of many different and distinct ethnic groups which are divided along cultural and religious lines. The country practices three major religious heritages namely: Islam, 50 per cent; Christianity, 40 per cent; and indigenous African religions, 10 per cent (CIA World Factbook, 2018). The major tribes in the country are: Hausa and Fulani, Yoruba, Igbo and Ijaw which are made of over 250 ethnic groups. The Hausa and Fulani have traditionally dominated in the north with a predominantly Muslim population. The Igbo and Ijaw dominate the South-East and South-South respectively with the majority of them practicing Christianity. The Yoruba are dominant in the South-West with over 50\% of them practicing Islam.

\subsection{The Nigerian Banking System: An Overview}

The history of the banking system in Nigeria could be traced back to colonial times from 1892 (Orjakor, 1999). The early banking activities in Nigeria started with the establishment of the African Banking Corporation and Bank of British West Africa (now known as First Bank of Nigeria (Onoja, 1998). The establishment of these banks were strongly influenced by the colonial ideologies to meet the commercial needs of the Colonial Government. However, between 1892 and 1959, the banking activities were not guided by any banking legislation, and as such anyone could set up a bank, provided it is registered under the Companies' Ordinance Act (Murinde \& Woldie, 2003; Hakim \& Kasenda 2018). In 1959, the apex bank, the CBN was established with the first banking ordinance act. It was to ensure orderliness in commercial banking, and prevent the establishment of non-viable banks and unregulated banking transactions (Alford, 2010). After the country gained its independence in 1960, the banking sector underwent several reforms with the most recent being in 2004. As at end-June 2004, there were 89 deposit money banks operating in Nigeria, comprising of institutions of various sizes and degree of soundness (Okafor, 2013). As part of the banking sector reform to achieve price stability, full employment, high economic growth and internal and external balances, the CBN increased the minimum capital requirement to N25billion, though some windows of opportunity to the then existing 89 banks including mergers, acquisition and the opportunity to raise funds from the capital market were offered (Okafor, 2013). On 31st December 2005, at the expiration of the consolidation only 20 banks emerged mostly through Merger and Acquisition (CBN, 2006).

In 2009, the second phase of the banking reform in Nigeria became imperative due to the global financial meltdown which started in 2007 (Sanusi, 2010; Hassan \& Kommers2018). Although the banking reforms have continued since the ones initiated in 2004 and 2009, the Nigerian banking system currently consists of 22 commercial banks, 980 micro-finance banks, 5 discount houses, 64 Finance Companies, and 6 development finance banks (CBN, 2017). The Nigerian commercial banks perform three major functions: accepting deposits, granting loans and operating payment and settlement mechanisms (Ahmed, Khalid, Ammar \& Shah, 2017).

\subsection{Islamic Banking in Nigeria}

The aspiration for the establishment of Islamic banking in Nigeria has generated much interest especially among the devout Muslims in the country. Over the years, there have been consistent effort towards the realization of this 
ambition; however, it has always met with stiff resistance from different religious groups. After several failed efforts, the CBN integrated non-interest banking into the Nigerian banking Act which now forms an important part of the country's banking system. In 1991, the CBN amended certain sections $\{9,23$ and 52 $\}$ of the Bank and Other Financial Institutions Act (BOFIA) which provided for the establishment of interest-free banking window in Nigeria (Usman, 2003).

According to the Act, non-interest banks are allowed to engage in trading, an activity prohibited in conventional commercial banking. Section 23(1) of the BOFIA 1991 explicitly provides for the licensing of non-interest banks. A non-interest bank has been defined as a bank that conducts banking activities, engages in trading, investments and commercial activities, including financial products and services based on Shari'ah principles (CBN, 2011). To operate non-interest banking in Nigeria, the CBN grants three types of licenses. These are (i) full-fledged non-interest bank or subsidiary, (ii) non-interest banking branch of a conventional bank, and (iii) non-interest banking window of a conventional bank. Additionally, the BOFIA 1991, Section 39 (1) gives a clear rule which prevents banks offering non-interest banking products and services from including the word "Islamic" as part of their registered name.

In line with the BOFIA provision, Habib Bank (now Keystone Bank) was given a provisional licence as the first Nigerian bank to operate an Islamic banking window in 1992, which was later approved by the CBN in 1997 (Bello, 2000). As part of the efforts to strengthen the Islamic banking system in Nigeria, in 2009, the CBN publicized the Framework for the Regulation and Supervision of Non-Interest Banks (NIBs) and subsequently, it released a new banking model, which included non-interest banks among the specialized banks in August 2010. In November, 2011, the CBN approved the full operations of the first and the only full-fledged Islamic bank in Nigeria, Jaiz Bank International. In the same year, it granted license to two conventional banks, Stanbic IBTC Bank and Sterling Bank to operate Islamic banking windows in the country. This policy marked a new milestone for the development of an Islamic financial system in Nigeria.

Currently, Jaiz bank international is the only full-fledged non-interest bank in Nigeria. It offers a wide range of Islamic financial products and services ranging from savings, current and investment deposit products. This enables the bank to share from the profits and losses of the business undertaken by its customers. However, to measure the success of Islamic banking in Nigeria, there is a need to investigate customers' behavioural intention to patronize Islamic banks. The absence of empirical evidence to proof the effect of attitude and societal influence on Islamic bank patronage is a gap intended to be addressed in this study. Hence, this study was, therefore, carried out using the theory of reasoned action (TRA) to empirically advance an understanding of the links between attitude, subjective norm, awareness, knowledge, religion and behavioural intention with respect to Islamic banking in Nigeria.

\subsection{Theoretical Framework}

The theoretical framework of this study was built based on the theory of reasoned action (TRA). The theory highlights the relationships between attitudes, subjective norms and behavioural intentions (Fishbein, 1967; Fishbein \& Ajzen, 1975). The TRA shows that behavioural intention of a person is influenced by attitude and subjective norm (Ajzen \& Fishein, 1980). In other words, a person's attitude or subjective norm is a determinant of his or her intention towards a particular behaviour (Ajzen \& Fishein, 1988). While attitude refers to a person's demonstration of a particular behaviour, subjective norm indicates an approval of certain behaviour by a referent group (Ajzen \& Madden, 1986; Hassan \& Jebin2018). For instance, when a person has a positive belief on the consequence of exhibiting a particular behaviour, he or she is most likely to display a positive attitude toward such behaviour, and vice versa. Similarly, if a person knows that his or her close acquaintances will support a particular behaviour, he or she will be influenced by the social factor to hold a positive subjective norm towards that behaviour, and vice versa (Ajzen, 1991).

The TRA has been applied in different areas of studies including Islamic finance (Fauziah, Taib, Ramayah, \& Abdul Razak, 2008; Bidin et al., 2009; Rahim \& Amin, 2011; Reni \& Ahmad, 2016), innovativeness and adoption (Gumel \& Othman, 2013) and intention (Muhammad, Haneef, \& Muhammed, 2016). The present study extends the application of this theory to an investigation on intentions to patronise Islamic banking. Although, some studies have explored a similar area in other countries (Echehabi \& Oladokun, 2012; Reni \& Ahmad, 2016), studies in this area are still scanty in the Nigerian context. Therefore, this study adapted the TRA model to provide an adequate explanation on intention to patronise Islamic banking in Nigeria. Since customers' opinion is very crucial to the survival of any organisation, the outcome of this study is expected to provide an insight on how the Islamic banking sector in Nigeria can remain efficient and competitive. 


\subsection{Hypotheses Development}

\subsubsection{Attitude}

Attitude is an important variable which reinforces behavioural intention (Ajzen and Fishbein, 1988). It shows a person's positive or negative belief, which ultimately influences his action to engage or not to engage in a particular behaviour. According to Ajzen (1991), attitude refers to a psychological proneness that a person expresses through favourable or unfavourable evaluation of a particular behaviour. Thus, a person with a positive belief will intend to execute a relevant behaviour. For example, when a person belief that an Islamic bank can meet his needs and expectations, he is most likely to have a positive attitude towards it and as such increase his likelihood of patronage.

Many studies on Islamic finance have shown the direct effect of attitude on the intention to patronise Islamic banking products. Such studies include Fauziah et al. (2008); Alam \& Sayuti (2011); Amin et al., (2011); Aliyu (2012); Huda et al., (2012); Sabirzyanov, (2016), among others. They found a significant relationship between attitude and intention to use Islamic finance products. Fauziah et al. (2008) conducted a study to establish the factors that determine the intention to participate in diminishing Musharakah home financing in Malaysia. They found a positive relationship between respondents' attitude and behavioural intention to participate in diminishing Musharakah. Diminishing Musharakah is a form of partnership which provides an avenue for a partner to buy the equity share of the other partner with a prearranged redemption schedule until the title to the equity is completely transferred. Similarly, in a study conducted by Echehabi \& Olaniyi, (2012) on the patronisation behaviour of Islamic banks' customers in Malaysia, found a positive relationship between attitude and behavioural intention. This study further extends this area of study by examining the direct effect of attitude on customers' behavioural intention towards Islamic banking in Nigeria, hence the first hypothesis is:

H1: Customers' attitude has a direct effect on their intention to participate in Islamic banking.

\subsubsection{Subjective Norm}

Subjective norm is the social influence on a person on whether or not to demonstrate a specific behaviour (Ajzen \& Fishbein, 1988). According to Ajzen (1991) and Ajzen and Fishbein (1980), a person's close associates like his or her family members, friends, and colleagues can influence him or her to carry out a particular action. In other words, if important people in a person's life want him to patronise Islamic banks, there is a high likelihood that he exhibits that behaviour.

A number of studies have examined the relationship between subjective norm and behavioural intention. They found that subjective norm has a positive and statistically significant impact on behavioural intention (Fishbein \& Ajzen, 1975; Ma'ruf et al., 2003; Ramayah, Ling, Norazah, \& Ibrahim 2005; Gopi and Ramayah; 2007; Abduh et al., 2011). Also, some studies like Amin et al. (2011), Golnaz et al. (2010), Echchabi \& Olaniyi, (2012), and Razak \& Abduh, (2012), among others, found that subjective norms have a significant influence in determining the intention to adopt Islamic banking services. For instance, Razak \& Abduh (2012) examined the diminishing partnership home financing acceptance among officers, managers and academicians in Kuala Lumpur. They found that subjective norm is statistically significant and had a positive effect on behavioural intention. Similarly, a study conducted in Nigeria using the TRA to determine behavioural intention to adopt the IMIM, found a significant and positive relationship between subjective norm and behavioural intention (Aliyu, 2012; Hassan \& Alanazi 2018). In other words, relatives and friends can influence the intention to patronise Islamic banks. Therefore, based on this premise, this study tested the second hypothesis:

$H 2$ : Subjective norm has a direct effect on customers' intention to participate in Islamic banking.

\subsubsection{Awareness}

Awareness could be defined as the acknowledgement, understanding, and exposure which stimulates an individual to act in a particular manner. The type of awareness an individual has has a remarkable impact on his attitude, behaviour, choice, decision and social and economic engagements. Bickford and Reynolds (2002) described awareness as an important component of social change which is based on the individuals' passive participation and interest towards certain issues. Thus, a person who is aware to a certain degree about the services and products of an Islamic bank is able to make an informed choice which influences his attitude towards the bank's services or products.

Previous studies have found a significant relationship between customers' awareness, attitude and intention to patronise Islamic banking. Such studies include; Abdul Hamid et al. (2011); Ayinde \& Echchabi, (2012); Faisal et al. (2014); Ramdhony (2013); Wahyuni \& Arifin, (2013); Yaseen et al., (2011). Similarly, Ayinde and Echchabi, (2012) 
and Mohammed and Ortmann, (2005) maintain that participation in product or services is influenced by the level of awareness. Ramdhony (2013) conducted a study on customers' awareness of Islamic banking terminology and their views of Islamic banking products in Mauritius. It was found that a majority of the respondents (82\%) had awareness while about $14 \%$ had no awareness of Islamic banking products. Likewise, Naser, Jamal and Al-Khatib (1999) conducted a study to investigate customers' level of awareness towards Islamic banking products covering 206 respondents. The study found that most of the customers have an awareness on specific products such as Mudarabah and Murabaha. Another study examined customers' awareness about Islamic banking in Singapore, and the findings revealed a lack of awareness among customers with regard to Islamic banking products and services (Suryanto, Haseeb, \& Hartani, 2018; Gerrard \& Cunningham, 1997). Therefore, to predict customers' attitude towards the Islamic banking system, it is essential to launch an awareness campaign to encourage a positive attitude towards the system. Hence, the propositions tested were:

H3: Customers' level of awareness has a direct effect on their attitude towards Islamic banking.

H3a: Attitude mediates the effect of customers' awareness on their behavioural intention towards Islamic banking.

\subsubsection{Knowledge}

Knowledge is the condition of knowing something with familiarity which comes from experience or education (Writz and Matilla, 2003). According to Davenport et al., (1998), knowledge is a reflection of person's awareness, experience, understanding, and interpretation related to a particular issue. Thus, customers' knowledge of Islamic banking is important to develop their understanding and subsequent patronage.

Previous studies have highlighted knowledge as an important determinant of customers' attitude and their subsequent intention to patronise Islamic bank products or services. Ren et al. (2011) posited that knowledge about the benefits of a product determines customers' attitude towards its purchase. Also, Haron et al (1994) examined bank patronage factors among Muslim and non-Muslim customers in Malaysia. They found that 63\% of Muslim respondents lacked adequate knowledge of Islamic banking and finance. Similarly, Chen and He, 2003; Wang et al., 2008, found a significant relationship between knowledge and intention. Also, Dineshwar 2013; Okumus, 2005; Priviledge, 2014 found that most of the non-Muslim respondents in Mauritius, Pakistan, Turkey, and South Africa respectively have limited knowledge of the Islamic banking products and services with the exception of the prohibition of interest. Therefore, to positively influence customers attitude and their subsequent intention to purchase Islamic banking products and services to both Muslims and non-Muslims, the Islamic banking sector needs continuous awareness campaign through several educative programmes to reach out to the public. Hence, the fifth hypothesis is:

H4: Customers' knowledge has a direct effect on their attitude towards Islamic banking.

$H 4 a$ : Attitude mediates the effect of customers' knowledge on their behavioural intention towards Islamic banking.

\subsubsection{Religion}

Religion signifies an important aspect which imbibes values in an individual and influences his attitude through life. In other words, it dictates the way of life and the interactions among humans in accordance with God's commandments. Although, religions cut across other doctrines, in Islam the means and processes which centre on the views of religion ( $d \bar{i} n$ ) differ. According to Belzen, 1999; Mokhlis, 2009, religion is one of the most important aspects of a cultural phenomenon, which has a significant effect on people's values, habits and attitudes. Thus, a person with religious commitment will intend to exhibit an attitude in line with the dictate of such a religion.

Many studies have examined the relationship between religion and intention. Such studies include, among others Alam et al. (2012); Amin et al. (2014); Echchabi \& Abd Aziz, (2012); Khan \& Khanna, (2010); Naser et al. (1999); Abou-Youssef et al. (2015); Zainuddin et al. (2004). They found that religion has a statistically significant effect on intention to adopt Islamic banking. According to a study conducted by Thomson Reuters in Tunisia in 2013, practice in accordance with Islamic principles is the most important factor that determines the selection of Islamic banking by customers. According to Souiden \& Marzouki (2015a), religion significantly influences consumers' attitude towards Islamic banking. Similarly, a study conducted to determine the intention to purchase Islamic life insurance, found a significant and positive relationship between religion and intention to purchase Islamic life insurance (Souiden \& Marzouki, 2015b). They argued that individuals that display high Islamic values have a more favourable attitude towards Islamic life insurance. A study by Abdullah and Abdul Rahman (2007) in Malaysia, found that $80 \%$ of the Muslim businessmen respondents' intention to use Islamic financing is a consequence of their religious beliefs commitment. In other words, religion can influence the intention to patronise Islamic banks. Based on this proposition, this study posited that: 
H5: Religion has a direct effect on customers' attitude towards Islamic banking.

H5a: Attitude mediates the effect of religion on customers' behavioural intention towards Islamic banking.

\section{Methods}

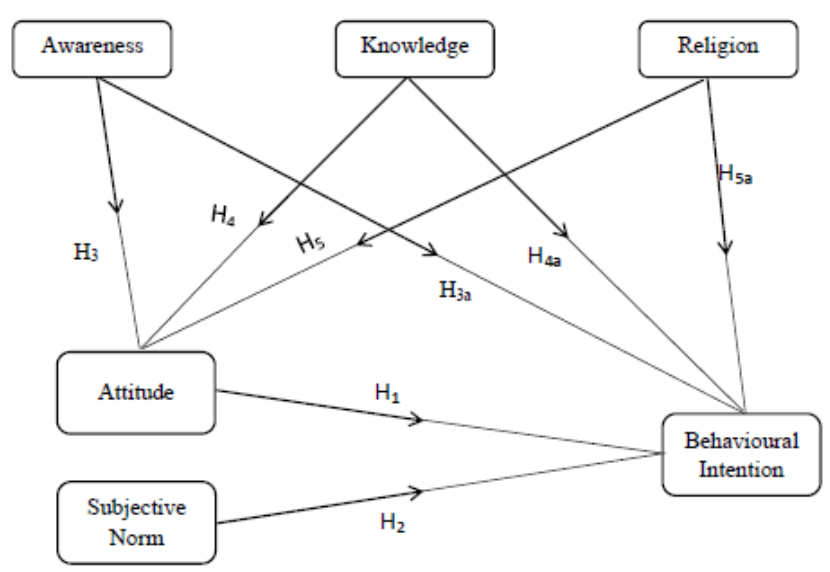

Figure 1: Research model

\subsection{Sample and Data Collection}

The sample was drawn from the population of customers of an Islamic bank in Nigeria. The sample comprised of different religious groups including Muslims and non-Muslims. The questionnaires were distributed using a convenience sampling technique. Given the nature of the present study, this technique was considered suitable as the participants were available for the study (Creswell, 2007). The respondents were requested to answer the questions on a 7-point Likert scale, with one (1) representing the lowest degree of acceptance and seven (7) reflecting the highest degree of acceptance. This range of choices was used to enhance a high level of consistency in scale measurement (Caruana, Ewing, \& Ramaseshan, 2000). A total of 420 questionnaires were distributed, out of which 274 responses were valid and thus, used for statistical analysis.

\section{Results}

\subsection{Data Analysis}

This study used structural equation modelling (SEM) statistical techniques to analyse the data. SEM is a useful statistical technique that simultaneously puts both the endogenous and exogenous variables into a statistical test (Byrne, 2001). In addition, it is valuable in inferential data analysis and hypothesis testing whereby the pattern of interrelatedness among the constructs of a study are specified a priori and grounded in established theory (Hoe, 2008). Based on the aforementioned and given the nature of this study, the structural model was considered the most suitable analytical instrument (Byrne, 2001).

\subsection{Characteristics of the Respondents}

The demographic profiles of respondents such as gender, age, religion, marital status, level of education, and religion were relevant to this study, thus they were examined prior to the actual analysis of data. This is essential as it provides detailed description of respondents' characteristics which help to better understand the collected data as suggested by (Robson, 2011). As shown in Table 1, the demographic information of the respondents in this study depicts various characteristics.

Table 1. Demographic profile of respondents

\begin{tabular}{|c|c|c|}
\hline Demographic Variables & Frequency & $\%$ \\
\hline \multicolumn{3}{|l|}{ Gender } \\
\hline Male & 93 & 33.9 \\
\hline
\end{tabular}




\begin{tabular}{|c|c|c|c|}
\hline & Female & 181 & 66.1 \\
\hline \multicolumn{4}{|l|}{ Age } \\
\hline & $21-25$ & 12 & 4.4 \\
\hline & $26-30$ & 67 & 24.5 \\
\hline & $31-35$ & 102 & 37.2 \\
\hline & $36-40$ & 36 & 13.1 \\
\hline & $41-45$ & 19 & 6.9 \\
\hline & $46 \&$ above & 38 & 13.9 \\
\hline \multicolumn{4}{|l|}{ Education } \\
\hline & Primary & 12 & 4.4 \\
\hline & Secondary & 117 & 42.7 \\
\hline & First Degree & 53 & 19.3 \\
\hline & Postgraduate & 49 & 17.9 \\
\hline & Others & 43 & 15.7 \\
\hline \multicolumn{4}{|l|}{ Religion } \\
\hline & Muslim & 98 & 35.8 \\
\hline & Non-Muslim & 176 & 64.2 \\
\hline \multicolumn{4}{|l|}{ Occupation } \\
\hline & Private & 47 & 17.2 \\
\hline & Public & 71 & 25.9 \\
\hline & Self-employed & 156 & 56.9 \\
\hline
\end{tabular}

Source: Authors' computation

In terms of gender composition of the respondents, the sample was predominantly female with $67.6 \%$, while the male contributed $32.4 \%$. The majority of the respondents were between $31-35$ years old (37.2\%) followed by 26-30 with $24.5 \%$ while the least is $21-25$ with $4.4 \%$. With regard to level of education, $4.4 \%$ of the respondents had primary education, $42.7 \%$ were secondary school certificate holders, and $19.3 \%$ with first degree certificate, $17.9 \%$ had a postgraduate degree, while the remaining $15.7 \%$ had a professional or equivalent qualification. In terms of religion, $62.2 \%$ of the respondents were non-Muslims compared to $35.8 \%$ of Muslims. This difference could be attributable to the fact that, Islamic banking does not discriminate along religious line. Besides, it also provides opportunities to both Muslims and non-Muslims. In terms of the occupational sector, a significant number of respondents were from the self-employed group constituting 56.9\%. Those in the public service represented $25.9 \%$, while the private sector represented $17.2 \%$.

\subsection{Reliability Test}

To test the internal consistency of the items of this study, the Cronbach's Alpha coefficient was used (Nunnally \& Bernstein, 1994; Creswell, 2009; Hair et al., 2010). As shown in Table 2, column 2, the reliability value for each construct is above the 0.70 as recommended in the SEM literature (Hair, et al, 2010; Nunnally, \& Bernstein, 1994; Bryman, 2012; Kline, 2011; Khan, Uddin \& Shathi 2018). This result validates good estimates of internal consistency and reliability of the questionnaire for further data analysis (Srinivisan, 1985; Nunnally \& Bernstein, 1994). Thus, the reliability results suggest a significant and acceptable internal consistency of the items.

\subsection{Measurement Model}

The study used the statistics from the measurement models to determine validity. The assessment of validity was conducted in two phases; convergent validity and discriminant validity. To establish convergent validity, average variance extracted (AVE) was examined as suggested by Hair et al. (2010). AVE represents the average variation in the observed variables that a latent construct is able to explain (Farrell, 2009; Khan, Hassan \& Marimuthu 2017). 
Table 2 shows that the AVE values for all constructs (attitude, awareness, knowledge, religion, subjective norm, and intention) are greater than the recommended values of 0.5 . Hence, the result demonstrated acceptable convergent validity (Nunnally, 1978; Chin et al., 1997).

The discriminant validity of the constructs was assessed using the square root of AVE compared to the squared correlation among the latent constructs (Bove et al., 2009; Hair et al., 2014; Keskin \& Korkutata 2018). Table 2 shows that the square roots of the AVE values are greater than the squared correlation for each construct. Thus, the result demonstrated acceptable discriminant validity (Fornell \& Larcker, 1981; Hair et al., 2014). Conclusively, the measurement model confirms the adequate convergent validity and discriminant validity of all the constructs.

Table 2. Convergent and discriminant validity

\begin{tabular}{llll}
\hline Constructs & Reliability & AVE & Square root of AVE \\
\hline Awareness & 0.819 & 0.75 & 0.87 \\
\hline Knowledge & 0.684 & 0.65 & 0.81 \\
\hline Religion & 0.767 & 0.72 & 0.85 \\
\hline Attitude & 0.854 & 0.61 & 0.78 \\
\hline Subjective Norm & 0.701 & 0.50 & 0.71 \\
\hline Intention & 0.799 & 0.56 & 0.75 \\
\hline
\end{tabular}

\subsection{Structural Model}

For a robust analytical approach, this study further tested the path analysis of the structural model. The results of the structural path model are shown in Figure 2. The $\mathrm{R}^{2}$ for Attitude and Behavioural Intention of the structural path model are shown in Figure 2. The model explained the variance in dependent variables: attitude of customers towards Islamic banking $\left(\mathrm{R}^{2}=0.64\right)$; behavioural intention $\left(\mathrm{R}^{2}=0.47\right)$. The results indicate that 64 per cent of the variation in attitude is explained by the three named variables; awareness, knowledge, and religion, while 47 per cent of the variation in behavioural intention is explained by attitude. In addition, this study examined the significance of the indirect effect of attitude on behavioural intention using the Sobel's test (Sobel, 1982; Baron \& Kenny, 1986). The result in Table 3 indicates that the indirect effect of awareness, knowledge, and religion on behavioural intention through attitude is significant. The results reveal these factors have a significant positive effect on customers' attitude towards Islamic banking in Nigeria, hence, supporting hypotheses 3, 4, and 5.

Table 3. Path structural model results

\begin{tabular}{llll}
\hline Relationship & $\begin{array}{l}\text { Path } \\
\text { Coefficient }\end{array}$ & $\begin{array}{l}\text { Standard } \\
\text { Errors }\end{array}$ & Result \\
\hline Awareness --> Attitude & 0.305 & 0.036 & Supported \\
\hline Knowledge --> Attitude & 0.432 & 0.019 & Supported \\
\hline Religion --> Attitude & 0.537 & 0.044 & Supported \\
Attitude--> Behavioural Intention & 0.343 & 0.041 & Supported \\
Subjective norm-->Behavioural Intention & 0.050 & 0.029 & Not supported \\
\hline
\end{tabular}

The results are consistent with the findings of Mokhlis (2009), Amin et al. (2014), Echchabi \& Abd Aziz (2012), Faisal et al. (2014), Ramdhony (2013), Chen and He (2003), Wang et al. (2008) that customers' attitude towards Islamic banking services is influenced by level of awareness, knowledge, and religion. Furthermore, the findings revealed the effect of attitude on behavioural intention supporting hypotheses 1 . The results are consistent with the findings in Fauziah et al. (2008), Alam \& Sayuti (2011), Amin et al. (2011), Abduh et al. (2011), Aliyu (2012), Huda et al. (2012), Ma'ruf et al. (2003), Ramayah, Ling, Norazah, \& Ibrahim (2005) that attitude is an important predictor of behavioural intention to participate in Islamic banking. 


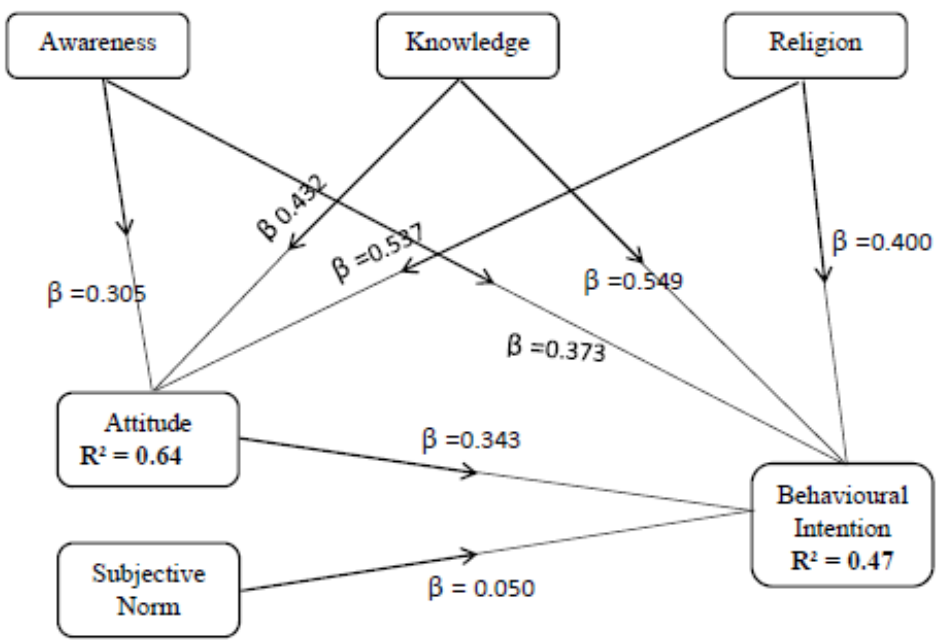

Figure 2. Structural path model

Table 4. Direct effect of awareness, knowledge, and religion on behavioural intention

\begin{tabular}{llll}
\hline Relationship & Path Coefficient & Standard Errors & Result \\
\hline Awareness --> Intention & 0.373 & 0.033 & Supported \\
Knowledge--> Intention & 0.549 & 0.030 & Supported \\
Religion--> Intention & 0.400 & 0.031 & Supported \\
\hline
\end{tabular}

Table 4 also reveals the significant path coefficient of the direct effect of the latent variables on the intention towards Islamic banking in Nigeria supporting hypotheses $3 \mathrm{a}, 4 \mathrm{a}$, and 5a. Although when attitude is controlled, the magnitude of the path coefficient reduced, it is still statistically significant. Nevertheless, since the direct effect is significantly different from zero, it indicates that attitude partially mediates the effect of awareness, knowledge, and religion on the intention towards Islamic banking in Nigeria.

\section{Discussion}

This study was a novel attempt to examine the behavioural intention to participate in Islamic banking in Nigeria using the theory of reasoned action (TRA). The results of the hypothesized structural model validated the robustness of the TRA in explaining consumers' intention to participate in Islamic banking in Nigeria. This study found that attitude positively and significantly influenced customers' intention as shown by a path loading (Figure 2). The value is greater than the minimum of 0.2 suggested by Byrne (2010). This implies that customers with good attitudes toward Islamic banking are most likely to be fascinated to participate in it. Hence, hypothesis 1 which states that attitude has a positive and significant effect on behavioural intention of customers to patronize Islamic banking services in Nigeria is supported. This finding is consistent with previous studies that have found that attitude is an important predictor of behavioural intention (Aliyu, 2012; Echehabi \& Oladokun, 2012; Amin et al., 2011; Golnaz et al., 2010; Razak \& Abduh, 2012).

The result for subjective norm was different, showing that subjective norm is not an important predictor of customers' intention to participate in Islamic banking as illustrated with path loading. This finding is in line with several other studies which found that subjective norm is insignificant in predicting behavioral intention (Echehabi \& Abd Aziz, 2012; Lewis et al., 2003; Chau \& Hu, 2001). However, it is not surprising to find a negative effect; this is possible such that this outcome may be due to a higher level of awareness and knowledge among respondents, whereby little or no opinion is needed from others before making a decision to patronise Islamic banking. Thus, based on the findings of this study, hypothesis 2 which states that subjective norm has a positive and significant influence on behavioral intention of customers to patronize Islamic banking is not supported. 


\section{Implications}

\subsection{Implication for the Banking Industry}

The results of this study can provide the Islamic banking sector and potential operators in Nigeria with relevant information on what influences customers' intention. Attitude is an important factor that predicts the intention to participate in Islamic banking, hence, policymakers, regulators and Islamic banking operators should formulate appropriate policy intervention targeted at attitude to improve the intention to participate. The Islamic banking sector must create awareness among the people which ultimately influences their attitude towards it. With this approach, the Islamic banking sector will be plausible, beneficial, and impactful, which means that there will be a wider choice and opportunities to be tapped by the people. More importantly, the bank should ascertain whether or not the potential customers hold negative attitudes towards it, understand the causes and develop a strategic approach to improve the situation through awareness campaigns and knowledge enhancement. The result suggests that creating proper awareness through effective communication with customers on the benefits of Islamic banking and the provision of a platform for knowledge enhancement will create positive attitude among different segments of the society and in turn influence their intention to participate. Besides that, it is important that the Islamic banking sector promotes inclusiveness and ensure ease of participation to bring about a positive impact on intentions.

\section{Conclusion}

This paper examined the mediating effect of attitude on customers' intention to participate in Islamic banking in Nigeria. The paper shows that attitude has a strong and significant effect on customers' intention to participate in Islamic banking, and also highlights the direct effect of awareness, religion, and knowledge on attitude and the indirect effects of these factors on intention.

This paper points out that the Islamic banking model provides robust opportunities for all while addressing the inherent challenges in society through Islamic law. The behavioural intention as well as the attitude towards Islamic banking can be enhanced by educating existing as well as potential customers. This can be done through awareness campaigns about Islamic banking services and products. Furthermore, Islamic banks need to inspire confidence in existing as well as potential customers as they will tend to influence their families and friends. In effect, the banks will be putting the two factors of the model into practice.

Future research should explore different methods of analyses such as a qualitative or mixed approach to provide robust results and also serve as overlapping evidence to enrich the information gained from the quantitative analysis. For instance, conducting further research by interviewing major players in the Islamic banking strategic decision making process including policymakers, staff, management, and the regulators, may provide further insight on their view on the intention to participate in Islamic banking in Nigeria. In addition, future research can focus on Islamic banking services and products taking into cognizance the impact of the demographic variables such as gender, age, and income levels. It is likely that some of these will have direct and indirect effects on the model.

\section{References}

Ahmed, U., Khalid, N., Ammar, A., \& Shah, M. H. (2017). Assessing moderation of employee engagement on the relationship between work discretion, job clarity and business performance in the banking sector of Pakistan. Asian Economic and Financial Review, $1197-121$. https://doi.org/10.18488/journal.aefr.2017.712.1197.1210

Ajzen, I. (1991). The theory of planned behaviour. Organizational Behavior and Human Decision Processes, 50, 179-211. https://doi.org/10.1016/0749-5978(91)90020-T

Ajzen, I., \& Fishein, M. (1980). Understanding Attitudes and Predicting Social Behavior. Prentice-Hall: Englewood Cliffs, NJ.

Ajzen, I., \& Madden, T. J. (1986). Prediction of goal-directed behavior Attitudes, intentions, and perceived behavioral control. Journal of Experimental Social Psychology, 22. https://doi.org/10.1016/0022-1031(86)90045-4

Ajzen, Icek, \& Fishbein, Martin. (1988). Theory of reasoned action-Theory of planned behavior. University of South Florida.

Alam S. S., \& Sayuti, N. M. (2011). Applying the Theory of Planned Behavior (TPB) in Halal food purchasing. International Journal of Commerce and Management, 21(1), 8-20. https://doi.org/10.1108/10569211111111676

Aliyu, D. M. (2012). Challenges of microfinance and the prospects of developing and introducing an Islamic 
micro-investment model in Nigeria. Unpublished Doctoral Dissertation, International Islamic University Malaysia, Kuala Lumpur.

Amin, H., Rahim Abdul Rahman, A., Laison Sondoh, S. Jr., \& Magdalene Chooi Hwa, A. (2011). Determinants of customers' intention to use Islamic personal financing: The case of Malaysian Islamic banks. Journal of Islamic Accounting and Business Research, 2(1), 22-42. https://doi.org/10.1108/17590811111129490

Bello, F. (2000, November 25). Emerging Opportunities for Divine Banking in Nigeria. Paper presented at the first Orientation Seminar on Islamic Banking and Finance in Nigeria (p.15), Kano, Nigeria.

Bidin, Z., Md-Idris, K., \& Mohd-Shamsudin, F. (2009). Predicting compliance intention on zakah on employment income in Malaysia: An application of reasoned action theory. Jurnal Pengurusan, 28, 85-102.

Bove, L.L., Pervan, S. J., Beatty, S. E., \& Shiu, E. (2009). Service worker role in encouraging customer organizational citizenship behaviors. Journal of Business Research, 62(7), 698-705. https://doi.org/10.1016/j.jbusres.2008.07.003

Bryman, A. (2012). Social Research Methods (4th ed.). Oxford: Oxford University Press.

Bryman, A., \& Cramer, D. (2005). Quantitative data analysis with SPSS 12 and 13. A Guide for Social Scientists. East Sussex Routledge. https://doi.org/10.4324/9780203498187

Burns, N., \& Grove, S. K. (2003). Understanding nursing research (3rd ed.). Philadelphia: W.B. Saunders Company.

Byrne, B. M. (2001). Structural equation modeling with AMOS: Basic concepts, applications and programming. Mahwah, NJ: Erlbaum.

Byrne, B. M. (2010). Structural Equation Modeling with AMOS: Basic Concepts, Applications, and Programming (2nd ed.). Routledge, New York, NY.

Byrne, B. M. (2012). Structural Equation Modelling With Mplus: Basic Concepts, Applications, and Programming (3rd ed.). New York, NY: Taylor \& Francis Group, LLC. https://doi.org/10.4324/9780203807644

Caruana, A., Ewing, M. T., \& Ramaseshan, B. (2000). Assessment of the three-column format SERVQUAL: An experiment approach. Journal of Business Research, 49(2), 57-65. https://doi.org/10.1016/S0148-2963(98)00119-2

Central Bank of Nigeria. (2006, January 3). Bank Consolidation: 25 Banks Meet December 31st Deadline. Press Release, Governor's Office.

Central Bank of Nigeria. (2011, June 12). CBN Issues New Guidelines for Non-Interest Banking. Central Bank of Nigeria Press Release.

Central Bank of Nigeria. (2017). Central Bank of Nigeria: List of Financial Institutions. Abuja. Central Bank of Nigeria (CBN). Retrieved 10 May 2017, from www.cbn.gov.ng/supervision/finstitutions.asp

Chau, P. Y. K., \& Hu, P. J. H. (2001). Information technology acceptance by individual professionals: a model comparison approach. Decision Science, 32(4), 699-719. https://doi.org/10.1111/j.1540-5915.2001.tb00978.x

Chin, W. W., Abhijit, G., \& William, D. S. (1997). Advancing the theory of adaptive structuration: The development of a scale to measure faithfulness of appropriation. Information Systems Research, 8(4), 342-367. https://doi.org/10.1287/isre.8.4.342

Coakes, S. J., \& Steed, L. (2007). SPSS Version 14.0 for windows: Analysis without anguish. Milton, Australia: John Wiley \& Sons.

Cohen, J. (1988). Statistical Power Analysis for the Behavioral Sciences (2nd ed.). Hillsdale, New Jersey, NJ: Lawrence Erlbaum Associates.

Conway, J. M., \& Huffcutt, A. I. (2003). A Review and Evaluation of Exploratory Factor Analysis Practices in Organizational Research. Organizational Research Methods, 6(2), 147-168. https://doi.org/10.1177/1094428103251541

Creswell, J. W. (1998). Qualitative inquiry and research design: Choosing among five traditions. Thousand Oaks, CA: Sage.

Creswell, J. W. (2009). Research Design: Qualitative, Quantitative, and Mixed Methods Approaches (3rd ed.). CA: Thousand Oaks, Sage Publications, Inc.

Cronbach, L. J. (1971). Test Validation: Educational Measurement (pp. 443-507). American Council on Education, 
R. L. Thorndike. Washington, D.C.

Dar, H. (2012, November 19). A word of caution on Sukuk financing. The Express Tribune.

Echchabi, A., \& Abd Aziz, H. (2012). Modelling the patronisation behaviour of Islamic banks' customers in Morocco. International Journal of Management and Strategy (IJMS), 3(5), 1-14. https://doi.org/10.3923/rjbm.2012.70.82

Ehlers, et al., (2009). The exploration of statistical methods in detecting random responding. Annual Meeting of the Society for Industrial/Organizational Psychology. Atlanta, GA. https://doi.org/10.1037/e518422013-599

Fauziah, T., Md, Ramayah, T., \& Abdul Razak, D. (2008). Factors influencing intention to use diminishing partnership home financing. International Journal of Islamic and Middle Eastern Finance and Management, l(3), 235-248. https://doi.org/10.1108/17538390810901168

Field, A. P. (2005). Discovering Statistics using SPSS. London, UK: Sage.

Fishbein, M. (1967). A behavior theory approach to the relations between beliefs about an object and the attitude toward the object. In M. Fishbein (Ed.), Readings in attitude theory and measurement (pp. 389-400). New York: Wiley.

Fishbein, M., \& Ajzen, I. (1975). Belief, Attitude, Intention, and Behavior: An Introduction to Theory and Research. Reading, MA: Addison-Wesley.

Fornell, C. G., \& Larcker, D. F. (1981). Evaluating Structural Equation Models with Unobservable Variables and Measurement Error. Journal of Marketing Research, 18(1), 39-50. https://doi.org/10.1177/002224378101800104

Froh, J. J. (2007). Data Screening Check List. Retrieved from http://people.hofstra.edu/Jeffrey_J_Froh/files/Data\%20Screening\%20Check \%20List_J.Froh.1.29.08.pdf on December 19, 2013

Global Islamic Finance Forum. (2014). Keynote Address by Governor at the Global Islamic Finance Forum 2014. Speech, Bank Negara Malaysia, Kuala Lumpur.

Golnaz, R., Zainalabidin, M., Mad Nasir, S., \& Eddie Chiew, F. C. (2010). Non-Muslims' awareness of halal principles and related food products in Malaysia. International Food Research Journal, 17, 667-674.

Gopi, M., \& Ramayah, T. (2007). Applicability of theory of planned behavior in predicting intention to trade online: some evidence from a developing country. International Journal of Emerging Markets, 2(4), 348-360. https://doi.org/10.1108/17468800710824509

Gorsuch, R. L. (1997). Exploratory factor analysis: Its role in item analysis. Journal of Personality Assessment, 68(3), 532-560. https://doi.org/10.1207/s15327752jpa6803_5

Gumel, A. M., \& Othman, M. A. (2013). Reflecting customers' innovativeness and intention to adopt Islamic banking in Nigeria. Business and Management Quarterly Review, 4(3\&4), 27-37.

Gyebi, F., Owusu, M., \& Etroo, J. K. (2013). Foreign Direct Investment and Gross Domestic Product in Ghana. International Journal of Academic Research in Accounting, Finance and Management Services, 3(3), $256-65$. https://doi.org/10.6007/IJARAFMS/v3-i3/153

Hair, et al. (1998). Multivariate Data Analysis (5th ed.). New Jersey, NJ: Prentice-Hall.

Hair, et al. (2006). Multivariate data analysis (6th ed.). Uppersaddle River, N.J.: Pearson Prentice Hall.

Hair, et al. (2010). Multivariate Data Analysis: A Global Perspective. London, UK: Pearson.

Hakim, L., \& Kasenda, F. (2018). Determinants of Capital Structure and their Implications Toward Financial Performance of Construction Service Companies in Indonesia Stock Exchange (IDX). International Journal of Asian Social Science, 8(8), 528-533. https://doi.org/10.18488/journal.1.2018.88.528.533

Hassan, H. S., \& Alanazi, T. M. (2018). Roles of Islamic Business Ethics in the Formation of Internal Organisational Culture: A Qualitative Approach of Muslims' SMEs in the UK. International Journal of Economics, Business and Management Studies, 5(1), 16-30. https://doi.org/10.20448/802.51.16.30

Hassan, M. H., \& Jebin, L. (2018). Comparative Capability of Migrant and Non-Migrant Households: Evidence from Rural Bangladesh. Asian Economic and Financial Review, 8(5), 618-640. https://doi.org/10.18488/journal.aefr.2018.85.618.640 
Hassan, M. I. A., \& Kommers, P. (2018). A Review on Effect of Social Media on Education in Sudan. International Journal of Educational Technology and Learning, 3(1), 30-34. https://doi.org/10.20448/2003.31.30.34

Hassan, M. K. (2005). The Cost, Profit and X-Efficiency of Islamic Banks: Economic Research Forum. 12th Annual Conference, Cairo, Egypt.

Hoe, S. L. (2008). Issues and procedures in adopting structural equation modeling technique. Journal of Applied Quantitative Methods, 3(1), 76-83.

Hoyle, R. H. (1995). The structural equation modelling approach: Basic concepts and fundamental issues. In R. H. Hoyle (Ed.), Structural equation modelling: Concepts, issues, and applications. California, CA: Thousand Oaks, Sage Publications, Inc.

Huda, N., Rini, N., Mardoni, Y., \& Putra, P. (2012). The analysis of attitudes, subjective norms, and behavioural control an muzakki's intention to pay zakah. International Journal of Business and Social Science, 3(22), 271-279.

Iqbal, Z. (1997). Islamic Financial Systems. Finance \& Development.

Jermsittiparsert, K. (2016). Culture of 'Elephant front legs-hind legs': A debate on the actuality of sexual politics in Thai society. The Social Sciences, 11(1), 20-28.

Keller, G., \& Warrack, B. (2004). Statistics for Management and Economics. Thomas Learning: California, CA: Brooks/Cole.

Keskin, Ö., \& Korkutata, A. (2018). Reviewing Academic Motivation Levels of Students Study in Different Faculties in Terms of Certain Variables (Sakarya University Case). Journal of Education and e-Learning Research, 5(2), 208-216. https://doi.org/10.20448/journal.509.2018.53.208.216

Khan, H., Hassan, R., \& Marimuthu, M. (2017). Diversity on corporate boards and firm performance: An empirical evidence from Malaysia. American Journal of Social Sciences and Humanities, 2(1), 1-8. https://doi.org/10.20448/801.21.1.8

Khan, M., Uddin, B., \& Shathi, I. J. (2018). Nature of Sexual Harassment Against the Female Students of Bangladesh: A Cross-Sectional Study in Tangail Municipality. International Journal of Social and Administrative Sciences, 3(2), 73-82. https://doi.org/10.18488/journal.136.2018.32.73.82

Kline, R. B. (2005). Principles and practice of structural equation modelling (2nd ed.). New York, NY: Guilford press.

Kline, R. B. (2011). Principles and practice of structural equation modelling (3nd ed.). New York, NY: Guilford Press.

Lewis, W., Agarwal, R., \& Sambamurthy, V. (2003). Sources of influence on beliefs about information technology use: an empirical study of knowledge workers. MIS Quarterly, 27(4), 657-678. https://doi.org/10.2307/30036552

Little, R. J. A. (1988). A test of missing completely at random for multivariate data with missing values. Journal of the American Statistical Association, 83, 1198-1202. https://doi.org/10.1080/01621459.1988.10478722

Ma'ruf, J. J., Mohamad, O., \& Ramayah, T. (2003). Intention to purchase via the internet: a comparison of two theoretical models. The Proceedings of the 5th Asian Academy of Management Conference "Challenges of Globalized Business: The Asian Perspective”. Hyatt Hotel, Kuantan, Pahang, Malaysia.

Manku, G. S., \& Motwani, R. (2002). Approximate frequency counts over data streams: Proceeding of the 28th International Conference on Very Large Data Bases (VLDB), pp. 346-357. https://doi.org/10.1016/B978-155860869-6/50038-X

Mason R. O., Lind, D. A., \& Marchal W. G. (1983). Statistics: An Introduction. New York, NY: Harcourt Brace Jovanovich, Inc.

Mohamed, S., \& Shaairi, N. A. (2013). Determinants of demand on family takaful in Malaysia. Journal of Islamic Accounting and Business Research, 4(1), 26-50. https://doi.org/10.1108/17590811311314276

Mueller, R. O. (1996). Basic principles of structural equation modelling: An introduction to LISREL and EQS. New York, NY: Springer-Verlag. https://doi.org/10.1007/978-1-4612-3974-1

Muhammad, D. A., Haneef, M. A., \& Mohammed, M. O. (2016). Intention to use the Islamic micro-investment 
model in Nigeria: empirical evidence. International Journal of Pluralism and Economics Education, 7(3), 283-299. https://doi.org/10.1504/IJPEE.2016.079689

Murinde, V., \& Woldie, A. (Ed) (2003). African Business and Finance Development Policy (Volume 4, No 2, p. 71). International Business Press, New York.

Nunnally, J. C. (1978). Psychometric Theory (2nd ed.). McGraw Hill Book Company, New York, NY.

Nunnally, J. C., \& Bernstein, I. H. (1994). Psychometric Theory (3rd ed.). New York, NY: McGraw-Hill.

Okafor, E. E. (2013). Reforms in the Nigerian Banking Sector and Strategies for Managing Human Resource Challenges. European Journal of Business and Management, 5(18), 127-137.

Onoja, I. R. (1998). The Contributions of Research Development in the Banking Industry in Nigeria. Nigerian Journal of Management Research, 210.

Pallant, J. (2011). SPSS survival manual. A step by step guide to data analysis using the SPSS program (4th ed.). Australia: Allen \& Unwin.

Rahim, F. A., \& Amin, H. (2011). Determinants of Islamic insurance acceptance: an empirical analysis. International Journal of Business and Society, 12(2), 37-54.

Ramayah, T., Ling, C. Y., Norazah, M. S., \& Ibrahim, M. (2005). Determinants of intention to use an online bill payment system among MBA students. E-Business, 9, 80-91.

Razak, D. A., \& Abduh, M. (2012). Customers' Attitude Towards Diminishing Partnership Home Financing in Islamic Banking. American Journal of Applied Science, 9(4), 593-599. https://doi.org/10.3844/ajassp.2012.593.599

Reni, A., \& Ahmad, N. H. (2016). Application of theory reasoned action in intention to use Islamic banking in Indonesia. Journal of Islamic Economics, 8(1), 137-148. https://doi.org/10.15408/aiq.v8i1.2513

Robson, C. (2011). Real world research: A resource for users of social research methods in applied settings. (3r ed.). Chichester, West Sussex: Wiley.

Sabirzyanov, R. (2016). Islamic financial products and services patronizing behavior in Tatarstan: the role of perceived values and awareness. Journal of King Abdulaziz University, Islamic Economics, 29(1), 111-125. https://doi.org/10.4197/Islec.29-1.10

Sanusi, L. S. (2010). Global Financial Meltdown and the Reforms in the Nigerian Banking Sector. CBN Journal of Applied Statistics, 2(1), 93-108.

Sekaran, U. (2003). Research methods for Business: A Skill Building Approac. (4th ed.). US: John Wiley\& Sons, Inc.

Sekaran, U., \& Bougie, R. (2009). Research method for business; a skill building approach (5th ed.). UK: John Wiley \& Son Ltd.

Suryanto, T., Haseeb, M., \& Hartani, N. H. (2018). The Correlates of Developing Green Supply Chain Management Practices: Firms Level Analysis in Malaysia. International Journal of Supply Chain Management, 7(5), 316.

Tabachnick, B. G., \& Fidell, L. S. (2001). Using Multivariate Statistics. Boston: Allyn and Bacon.

Tabachnick, B. G., \& Fidell, L. S. (2007). Using multivariate statistic (5th ed.). Boston: Pearson Education Inc.

Tag el-Din, S. I. (2005b). Review of Iqbal, M. and Molyneux, P. (2005) Thirty Years of Islamic Banking: History, Performance and Prospects. Muslim World Book Review, 25(3), 42-46.

Usman, S. (2003). The Legal and Regulatory Issues of Islamic Banking in Nigeria. In Sulaiman, S. and Galadanci, B. (Eds.), Islamic Banking: General Framework and Case Studies. Kano: International Institute of Islamic Thought (IIIT).

Wiersma, W. (1991). Research methods in education: An introduction (5th ed.). Boston: Allyn \& Bacon.

World Bank. (2016). World Development Indicators. Washington, D.C.

Yusuf, M.-B. O., Meera, A. K. M., Ghani, G. M., Manap, T. A. A., \& Larbani, M. (2015). Acceptance of gold as an alternative currency: an empirical validation of adoption of innovation theory. Asian Journal of Business and Accounting, 8(2). 